\title{
Use of Moringa Oleifera Seeds as a Biosorbent and Antimicrobial Agent in Acidic Mineral Effluents
}

Pauline Ncube ( $\triangle$ ppncube01@gmail.com )

University of Johannesburg - Doornfontein Campus https://orcid.org/0000-0002-5468-5450

Freeman Ntuli

University of Johannesburg - Doornfontein Campus

Thabo Falayi

Malawi University of Science and Technology

\section{Research Article}

Keywords: environmental pollution, water treatment, Moringa oleifera, Acid Mine Drainage, biosorbent, antimicrobial agent

Posted Date: August 13th, 2021

DOl: https://doi.org/10.21203/rs.3.rs-794787/v1

License: (c) (i) This work is licensed under a Creative Commons Attribution 4.0 International License. Read Full License 


\section{Abstract}

Moringa Oleifera (MO) seed extract was used as an antimicrobial agent and a biosorbent to remove heavy metals from acidic mineral effluents. Biosorption experiments were conducted in a thermostatic shaker using synthetic acidic mineral effluent(SAME) of composition, 20 ppm, 20 ppm, 100 ppm, and 500 $\mathrm{ppm}$ for $\mathrm{Ni}, \mathrm{Cu}, \mathrm{Mn}$, and $\mathrm{Fe}$, respectively. The Quanti-tray and SimPlate standard procedures were used for the antimicrobial tests. The aqueous seed extract achieved microbial reductions of $100 \%$ total coliform and $90.5 \%$ Heterotrophic Plate Count (HPC). Ni and Cu were the most removed metals and optimum sorption conditions achieved were $\mathrm{pH}=3$, Temperature $=308 \mathrm{~K}$, solid loading $=10 \% \mathrm{~m} / \mathrm{v}$, and residence time $=90$ minutes. The biosorption process was endothermic for all the metals but only feasible and spontaneous for $\mathrm{Cu}$ and $\mathrm{Ni}$. The Langmuir model and second-order kinetics best fit the adsorption process for $\mathrm{Ni}, \mathrm{Cu}$, and $\mathrm{Fe}$, while ion-exchange/ chemisorption was the possible mechanism of adsorption. Overall, $\mathrm{MO}$ seed extract was an effective antimicrobial agent and bio-sorbent for $\mathrm{Ni}$, $\mathrm{Cu}$, and Fe removal in acidic mineral effluent. The use of $\mathrm{MO}$ in acidic medium is a novel technique.

\section{Introduction}

Water is an essential basic commodity for life. Lack of safe drinking water is mainly due to water contamination in rivers and dams caused by continued growth in industrial and urban centers. Heavy metal pollution from mining, milling, electroplating, and surface finishing industries often results in acidic mineral effluents such as acid mine drainage (AMD), which discharges a range of toxic metals, including $\mathrm{Fe}, \mathrm{Cu}, \mathrm{Ni}, \mathrm{Mn}, \mathrm{Pb}$, and $\mathrm{Co}$ into the environment. Thus, AMD-contaminated water poses a considerable threat to the environment. The water could channel its way into the ecosystem, causing pollution in surface water and subsequently groundwater close to the mining areas, whether active or abandoned. Heavy metals, unlike organic pollutants, are non-biodegradable and can accumulate in living tissue resulting in adverse health problems (Zhang, 2011).

Consequently, heavy metal removal from acidic mineral effluents such as AMD has been one of the major global concerns for years. In South Africa, the Gauteng region has been classified as a top priority area requiring immediate action due to the vast environmental impact of AMD and lack of adequate measures to address it (Inter-Ministerial Report, 2010). Traditionally, the treatment of AMD involves neutralization with limestone $\left(\mathrm{CaCO}_{3}\right)$ or slaked lime $\left(\mathrm{Ca}(\mathrm{OH})_{2}\right)$, giving rise to the formation of metal hydroxides and precipitates of aluminum and iron. In addition, the treatment produces voluminous gypsum $\left(\mathrm{CaSO}_{4}\right)$ sludge containing radioactive elements, which presents disposal problems (Falayi, 2014). To be rendered fit for human consumption and other domestic purposes, acidic mineral effluents would have to undergo further treatments, including turbidity removal and disinfection. Aluminum sulfate (alum) is commonly used as a primary coagulant/flocculent in most conventional water treatment plants (WTPs) to remove turbidity, but it has its demerits. It may lead to high aluminum residual content in treated water, which has been shown to promote diseases like Alzheimer's disease [Kaser et al., 1990]. Its use also results in the production of voluminous sludge, adding to the disposal challenges. Chlorination, on the other hand, is the most widely used method for disinfection. However, chlorine has been linked to the potential 
formation of carcinogenic and mutagenic disinfection by-products (DBPs) related to increased risks of cancers, heart diseases, and birth defects. Chlorine also suffers from decay, reduced concentration down the distribution network (Devarakonda et al., 2010), and production of voluminous sludge, which further contributes to environmental pollution. Combined with the high cost of chemicals, these shortcomings present a considerable water treatment challenge, particularly in developing countries with scarce resources and poor infrastructure.

The application of natural materials derived from plants in water treatment has increased in recent years. However, of all the studied plant materials, $\mathrm{MO}$ seeds have shown promising results as a natural coagulant and biosorbent in water treatment with its performance compared to Alum (Ali et al., 2010; Ghebremichael, 2004). The plant is classified under the single genus Moringaceae family, which constitutes trees indigenous in the tropical region but cultivated in other areas, including South Africa (Suleyman et al., 1994). The seed extracts offer several advantages over conventional water treatment and AMD treatment methods, including zero $\mathrm{pH}$ effect on water, low cost, wide availability, no potential health problems, and bio-degradable sludge production (Cochrane et al., 2006; Ndabigengesere et al., 1998). In drinking water clarification, the dried seed suspension acts as a natural coagulant (Arora et al., 2013). This is attributed to the presence of a water-soluble cationic coagulant protein which binds the predominantly negatively charged particulate matter that causes turbidity in water (García-Fayos et al., 2010). High levels of turbidity often indicate high levels of pathogens such as bacteria, viruses, and parasites. MO seeds exert antimicrobial activity against many microbes, including bacteria and fungi (Masden et al., 1987). Suleyman et al. (1994) reported turbidity and bacterial load reductions of 80-99.5\% and $90-99.9 \%$, respectively, after 2 hours of Nile water treatment using MO seeds (Suleyman et al., 1994). Similar findings were reported in later studies by Mohan et al. (2008), Bukar et al. (2010), and Walter et al. (2011). The active antimicrobial agent acts by coagulating the solid matter in water combining it with suspended bacteria for easy removal, hence removing them in the process (Jahn, 1988).

The biosorbent property of moringa seeds qualifies them as a suitable, cost-effective biosorbent alternative for heavy metal remediation in acidic mineral effluents. The biosorption process may be facilitated by the interaction of metal ions $\left(\mathrm{Me}^{2+}\right)$ with the carboxyl ligands of amino acids present in $\mathrm{MO}$ seeds (Kumara et al., 2005). Most of these amino acids exhibit isoelectric points between pH 4.0-8.0 and exist in an ionized state in this $\mathrm{pH}$ range (Delvin, 2002). Thus, indicating that $\mathrm{MO}-\mathrm{Me}^{2+}$ ion binding could proceed via an ion-exchange mechanism driven by electrostatic attraction between $\mathrm{Me}^{2+}$ and negatively charged substrates of amino acids (Sharma et al., 2005). However, the complete biosorption mechanism is still not fully understood. The potential mechanism of biosorption may include one or a combination of ion exchange, adsorption, micro precipitation, complexation, chelation, and coordination (Giri, 2012).

It has been noted that much work has been done on the application of $\mathrm{MO}$ as a coagulant/flocculant and antimicrobial agent in the treatment of water. However, its application in the treatment of acidic mineral effluents such as AMD is still limited. Therefore, this study sought to establish the effectiveness of MO seed extracts as an alternative antimicrobial agent and biosorbent in the treatment of acidic mineral effluents for disinfection and heavy metal removal, respectively. 


\section{Materials And Methods}

\subsection{Reagents and Chemicals}

MO seeds were supplied by Rangex (PTY) LTD and used as a biosorbent and antimicrobial agent in the adsorption and antimicrobial activity experiments, respectively. SAME was prepared to fully represent the concentration range usually found for AMD in Witwatersrand, South Africa. The chemicals $\mathrm{CuSO}_{4} \cdot 5 \mathrm{H}_{2} \mathrm{O}$, $\mathrm{NiSO}_{4} .7 \mathrm{H}_{2} \mathrm{O}, \mathrm{FeSO}_{4} .5 \mathrm{H}_{2} \mathrm{O}$ and $\mathrm{MnSO}_{4} .5 \mathrm{H}_{2} \mathrm{O}$ were supplied by C.C. Imelmann (PTY) LTD. Appropriate dilutions of $1000 \mathrm{ppm}$ standard solutions of $\mathrm{Ni}, \mathrm{Cu}, \mathrm{Fe}$ and $\mathrm{Mn}$ were prepared for Atomic Absorption Spectroscopy (AAS) calibration. $\mathrm{HNO}_{3}$ and $\mathrm{HCl}$ were used for AAS sample digestion and preservation. 0.1 $\mathrm{M} \mathrm{HCl}$ and $0.1 \mathrm{M} \mathrm{NaOH}$ were used for $\mathrm{pH}$ adjustment.

\subsection{Characterisation of MO Seeds}

The structural elucidation of MO seeds was determined using FTIR (Thermo scientific Nicket (IS10) employing DTGS KBR detector and KBR beam splitter. The spectra were obtained over a range of 800-

$4000 \mathrm{~cm}^{-1}$ with a resolution of $2 \mathrm{~cm}^{-1}$ and optical velocity of 0.6329 . XRF (Rigaku ZSX Primus 11) was used to establish the seed chemical composition. The X-ray source was set at High-Frequency Inverter type with a maximum rating of $4 \mathrm{~kW}, 60 \mathrm{kV}-150 \mathrm{~mA}$, whereas the primary beam filter and diaphragm were operated at four Filters (Al, Al-2, Cu, Zr) and six-position Automatic Exchanger modes, respectively.

\subsection{Adsorption experiments}

\subsubsection{Sample preparation}

SAME constituting of 20 ppm Ni, 20 ppm Cu, 100 ppm Mn and 500 pm Fe was prepared in a $2000 \mathrm{ml}$ volumetric flask by adding appropriate amounts of metal sulphate salts and diluting to volume with reverse osmosis water (RO). This served as the SAME stock solution with an initial pH of 3.36. MO seed kernels were ground to fine powder and dried in the oven at $313 \mathrm{~K}$ for 24 hours using the mortar and pestle. This constituted the stock seed extract.

\subsubsection{Sample pre-treatment (AAS Analysis)}

Before AAS analysis, sample digestion was carried out on treated samples to eliminate organic content and convert target metals into soluble. The procedure involved measuring and transferring $50 \mathrm{ml}$ of filtered (treated) sample into a $100 \mathrm{ml}$ volumetric flask, followed by acidification with $2 \mathrm{ml}$ of 1:1(v/v) $\mathrm{HNO}_{3}: \mathrm{H}_{2} \mathrm{O}$ and $1 \mathrm{ml}$ of $1: 1(\mathrm{v} / \mathrm{v}) \mathrm{HCl}: \mathrm{H}_{2} \mathrm{O}$. The sample was then heated on a hot plate and allowed to evaporate to a residual volume of $\approx 20 \mathrm{ml}$. After cooling, $20 \mathrm{ml}$ was transferred into a $25 \mathrm{ml}$ volumetric flask and diluted to volume with RO water. The sample was then ready for AAS analysis.

\subsubsection{Effect of solid loading, $\mathrm{pH}$, temperature, and time}

The effect of solid loading was investigated to determine the optimum MO dosage required to achieve the highest metal removal efficiency from SAME. Appropriate amounts (g) of milled MO seeds were 
added to $50 \mathrm{ml}$ of SAME in separate $250 \mathrm{ml}$ Erlenmeyer flasks to make sample solutions of $2 \%, 4 \%, 6 \%$, $8 \%$, and $10 \%$ solid loading. After measuring initial $\mathrm{pH}$, the acidic mineral solution was agitated for $4 \mathrm{~h}$ at $150 \mathrm{rpm}$ in a Labotec Orbishaker, thermostatic shaker maintained at 298K, to initiate the adsorption/biosorption process. Samples were taken at intervals of $30 \mathrm{mins}$, filtered using a vacuum filter pump, and $\mathrm{pH}$ measurements were done on the filtrate. This was followed by sample digestion (2.3.2), after which samples were stored ready for AAS analysis. The procedure was repeated for the other investigations, each time using optimum conditions obtained in the preceding experiments; $\mathrm{pH}(2,3,4,5$, $6,7)$, temperature $(298,308,318 \mathrm{~K})$, and time( $0-240 \mathrm{mins})$. All experiments were done in triplicate to ensure accuracy.

\subsubsection{Re-use of spent (metal-loaded) MO seeds.}

Milled MO seeds residue cake obtained after filtration in the adsorption experiments was dried for $12 \mathrm{~h}$ in an oven set at $323.11 \mathrm{~K}$. The dry spent MO seed cake was then ground to a fine powder using a mortar and pestle. Solid loading, $\mathrm{pH}$, time, and temperature were adjusted to optimum conditions and adsorption process initiated as described in 2.3.3. The procedure was repeated two more times, using loaded MO seed residual cake obtained from the preceding experiment.

\subsubsection{Desorption of spent MO seeds}

1. $2.5 \mathrm{~g}$ of spent $\mathrm{MO}$ seeds were added to $100 \mathrm{ml}$ of $0.05 \mathrm{M} \mathrm{HNO}_{3}$ and subjected to adsorption for $2 \mathrm{~h}$ as described in 2.3.3. This was followed by AAS analysis.

\section{2.4 Antimicrobial activity experiments}

\subsubsection{MO seed extracts}

The MO stock seed extract prepared in 2.3.1 was used to form the raw extract, while the other portion was used to prepare the aqueous extract. To prepare the latter, a portion of the raw seed extract was defatted in $5 \%(\mathrm{w} / \mathrm{v}) \mathrm{n}$-hexane suspension and stirred with a magnetic stirrer for $60 \mathrm{~min}$. This was followed by centrifuging at $3000 \mathrm{rpm}$ for $45 \mathrm{~min}$ to separate the supernatant while the settled powder was allowed to dry at room temperature for $24 \mathrm{~h}$. The defatted dry powder was then mixed with RO water, stirred for 60 $\mathrm{min}$, and allowed to settle for a further $20 \mathrm{~min}$. This was followed by filtration, after which the filtrate was stored as the aqueous extract stock solution ready for antimicrobial experiments.

\subsubsection{Antimicrobial Activity}

The effect of $\mathrm{MO}$ seeds as an antimicrobial agent was determined by investigating the reduction in total microbial load of the synthetic wastewater samples after separate treatments with $\mathrm{MO}$ raw extract and aqueous extract at $\mathrm{MO}$ dosages of $50 \mathrm{mg} / \mathrm{l}, 100 \mathrm{mg} / \mathrm{l}$ and $150 \mathrm{mg} / \mathrm{l}$. The Quanti-tray and SimPlate procedures as outlined in the 'Standard Methods for the Examination of Water and Wastewater' guidelines were used.

\subsubsection{Effect of MO seed extracts on coliforms}


The Quanti-Tray* Enumeration Procedure was performed. The main objective was to either detect E. coli and total coliforms simultaneously or fecal coliforms in water. E. coli, Klebsiela and Pseudomonas were used as control microbes in this study. The results were presented as Most Probable Number (MPN/100 $\mathrm{ml}$ ), which gives an indication of the most probable number of total bacteria in water samples.

\subsubsection{Effect of MO seed extracts on heterotrophic plate count (HPC)}

The simPlate procedure was used. The method gives the quantity of HPC (bacteria, yeast, moulds) in water indirectly by testing for the presence of critical enzymes found in these organisms. The results are presented as MPN/100 ml.

\section{Results And Discussion}

\subsection{Adsorption process}

\subsubsection{Effect of Solid Loading}

Figure 1 shows that removal efficiency increases by $2.96 \%, 4.94 \%$, and $7.29 \%$ for $\mathrm{Mn}, \mathrm{Ni}$, and $\mathrm{Cu}$ at $10 \%$ $\mathrm{m} / \mathrm{v}$, respectively, thus making it the optimum solid loading achieved. The Single Factor ANOVA analysis applied at $8-10 \%(\mathrm{wt} / \mathrm{v}$ ) solid loading (Table S1-S1.2) proved the increase to be statistically significant at the $5 \%$ significance level, with $\mathrm{n}=3$ for only $\mathrm{Ni}$ and $\mathrm{Cu}$. Therefore, solid loading influences $\mathrm{Ni}$ and $\mathrm{Cu}$ removal from acidic mineral waters. The observed improvement in metal removal efficiency could be due to increased surface area, leading to more available active sites and a subsequent higher degree of adsorption. Metal removal followed the order; $\mathrm{Ni}>\mathrm{Cu}>\mathrm{Fe}>\mathrm{Mn}$. The physicochemical properties of metal ions are presented in Table 1 and could be responsible for the observed removal trend.

Table 1

Physicochemical properties of metal ions

(source: Bhatt, 2015; Pauling scale-periodic table)

\begin{tabular}{|lllll|}
\hline Metal ion & lonic radius & Electronegativity & Electron configuration & Para magnetism \\
\hline $\mathrm{Ni}^{2+}$ & 0.55 & 1.91 & $(\mathrm{Ar}) 3 \mathrm{~d}^{8} 4 \mathrm{~S}$ & weakly \\
\hline $\mathrm{Cu}^{2+}$ & 0.57 & 1.90 & $(\mathrm{Ar}) 3 \mathrm{~d}^{9} 4 \mathrm{~S}$ & weakly \\
\hline $\mathrm{Fe}^{2+}$ & 0.63 & 1.83 & $(\mathrm{Ar}) 3 \mathrm{~d}^{6} 4 \mathrm{~S}$ & Highly \\
\hline $\mathrm{Mn}^{2+}$ & 0.66 & 1.55 & $(\mathrm{Ar}) 3 \mathrm{~d}^{5} 4 \mathrm{~S}$ & Highly \\
\hline
\end{tabular}

Table 1 shows a decrease in the ionic radius following the order: $\mathrm{Mn}>\mathrm{Fe}>\mathrm{Cu}>\mathrm{Ni}$, which resonated with the observed increase in removal efficiency. To explain this, it was considered that the smaller the metal ion, the closer it can get to the active site and the tighter it can be bound. Hence there would be a stronger 
attraction for it than larger metal ions. On the other hand, a decrease in electronegativity followed an opposite trend: $\mathrm{Ni}>\mathrm{Cu}>\mathrm{Fe}>\mathrm{Mn}$. However, higher electronegativity results in enhanced adsorption tendency of $\mathrm{Me}^{2+}$ (Gorgievskia et al., 2013; Zhang 2011), which is consistent with the findings of this study. Therefore, the smaller the ionic radius, the larger the electronegativity and the higher the affinity of $\mathrm{Me}^{2+}$ ions for active sites.

\subsubsection{Effect of pH}

Fig.2 Variation of metal removal with initial pH. [Conditions: $\mathrm{C}_{\mathrm{o}}=20 \mathrm{ppm} \mathrm{Cu}, 20 \mathrm{ppm}, \mathrm{Ni}, 100 \mathrm{ppm} \mathrm{Mn}$, $500 \mathrm{ppm}$ Fe; solid loading $=10 \% \mathrm{~m} / \mathrm{v}$, Temperature $=298 \mathrm{~K}$

Metal removal increases of $69.6 \%, 68.6,57.0 \%$, and $22.4 \%$ were achieved for $\mathrm{Cu}, \mathrm{Ni}, \mathrm{Fe}$, and $\mathrm{Mn}$, respectively, from $\mathrm{pH} 2$ to $\mathrm{pH} 3$ (Fig. 2). The increase was proven to be statistically significant at the $5 \%$ significance level with $n=3$, for all the metals using the ANOVA analysis (Table S1.3-S1.6) at pH 2-3. Thus, metal removal for $\mathrm{Ni}, \mathrm{Cu}, \mathrm{Fe}$, and $\mathrm{Mn}$ was primarily influenced by $\mathrm{pH}$, and $\mathrm{pH} 3$ was the optimum $\mathrm{pH}$ achieved. Metal removal remained relatively constant with a further increase in $\mathrm{pH}$ up to 7 , thus indicating sorption equilibrium. The rise in metal removal from $\mathrm{pH} 2$ to 3 could be attributed to metal ions $\left(\mathrm{Me}^{2+}\right)$ competing more favourably than $\mathrm{H}^{+} / \mathrm{H}_{3} \mathrm{O}^{+}$ions for biosorbent active sites (since $\mathrm{H}^{+}$concentration is lower). Thus, resulting in higher metal uptake and consequently higher removal efficiency and vice-versa for $\mathrm{pH}<3$.

Furthermore, at $\mathrm{pH}<3$, the adsorbent surface area is positively charged, hence exhibits negligible affinity for $\mathrm{Me}^{2+}$ ions (Farooq et al., 2010). Figure 2 further shows that Mn removal was very poor, which could be attributed to its lower affinity for active binding sites due to its lower electronegativity and higher ionic radius. However, at a $\mathrm{pH}$ range of $6-7$, a $49.9 \%$ increase in $\mathrm{Mn}$ removal was achieved. $\mathrm{Mn}$ (II) could have possibly been oxidized to $\mathrm{Mn}$ (III/IV) during $\mathrm{pH}$ adjustments using $\mathrm{NaOH}$ and therefore precipitated as $\mathrm{MnO}_{\mathrm{x}}$ (Pinto and Al-Abedb 2011) at this $\mathrm{pH}$ range. Therefore $\mathrm{Mn}$ removal was probably via precipitation mechanism to a more significant extent. Traditionally, $\mathrm{Mn}$ removal from acidic mineral waters is low (Deepti et al., 2016)

\subsubsection{Effect of contact time}

Metal removal efficiency increased with time reaching maximum levels of $90.0 \%, 81.2 \%$, and $69.2 \%$ for $\mathrm{Ni}$, $\mathrm{Cu}$, and $\mathrm{Fe}$, respectively, at 90min residence time (Fig. 3). The ANOVA analysis applied at 30-90 mins showed a statistical significance in $\mathrm{Ni}, \mathrm{Cu}$, and Fe removal at the $5 \%$ significance level with $\mathrm{n}=3$ (S1.7$\mathrm{S1-9)}$. Therefore, removal efficiency for $\mathrm{Ni}, \mathrm{Cu}$, and $\mathrm{Fe}$ was due to an increase of residence time from 3090 mins, with 90 mins being the optimum residence time achieved. A decline then followed this in $\mathrm{Cu}$ removal while static levels were achieved for $\mathrm{Ni}$ and $\mathrm{Fe}$ at sorption equilibrium. The initial increase in metal removal may be ascribed to the sizeable biosorbent contact surface area available at the start of the biosorption process as many active binding sites are still unoccupied. However, as adsorption proceeds, the number of available active sites diminishes, and the biosorption rate slows down until sorption equilibrium is reached. At this stage, $\mathrm{Me}^{2+}$ ions compete significantly for the few remaining 
active sites. The mechanism responsible for the rapid metal removal phase could be physical adsorption or ion exchange at the surface of biosorbent, while the slower phase could be due to other mechanisms such as aggregation, micro-precipitation, and saturation of binding sites (Pinto and Al-Abedb 2011).

\subsubsection{Effect of temperature}

Figure 4 shows that from $298 \mathrm{~K}$ to $308 \mathrm{~K}$, there was an increase of $28.5 \%, 20.7 \%, 36.0 \%$, and $7.7 \%$ removal efficiency for $\mathrm{Ni}, \mathrm{Cu}, \mathrm{Fe}$, and $\mathrm{Mn}$. The increase in metal removal was proven by ANOVA analysis at $298 \mathrm{~K}-308 \mathrm{~K}$ (Table S1.10-S1.13) to be statistically significant for Mn at a 5\% significance level. Thus, metal removal was dependent on temperature. The optimum temperature achieved was $308 \mathrm{~K}$. Further temperature increases to $318 \mathrm{~K}$ resulted in a decline in removal efficiency, which was more pronounced for $\mathrm{Mn}$ and $\mathrm{Fe}$ at $33.2 \%$ and $12.3 \%$ respectively.

The enhancement of metal removal with increasing temperature demonstrated the endothermic nature of the biosorption process. Increasing temperature led to increased kinetic energy and surface activity of metal ions. Thus, promoting additional metal binding capacity. Furthermore, the observed increase in metal removal with temperature could be ascribed to the decreased boundary layer thickness surrounding the biosorbent. The net effect reduces the mass transfer resistance of $\mathrm{Me}^{2+}$ ions in the boundary layer (Reddy et al., 2010). On the other hand, the decrease in metal removal observed at $318 \mathrm{~K}$ was most probably due to the damage done to the physical structure of the bio sorbent resulting in loss of adsorption capacity. Structure highly defines protein functionality, thus at high temperatures, the tertiary structure and therefore functionality of the Moringa bioactive functional groups are destroyed since they are proteinaceous in nature.

\subsection{Biosorption thermodynamics}

Table 2

Thermodynamic parameters influencing adsorption process.

\begin{tabular}{|lllll|}
\hline $\begin{array}{l}\text { Metal ion } \\
\text { Temperature/K }\end{array}$ & Metal & $\begin{array}{l}\Delta \mathrm{H}_{\circ} \\
(\mathrm{KJ} / \mathrm{mol})\end{array}$ & $\begin{array}{l}\Delta \mathrm{S}_{\bullet} \\
(\mathrm{KJ} / \mathrm{mol})\end{array}$ & $\begin{array}{l}\boldsymbol{\Delta} \mathrm{G} \\
(\mathrm{KJ} / \mathrm{mol}) \\
\mathbf{2 9 8 3 0 8 3 1 8}\end{array}$ \\
\hline & $\mathrm{Ni}$ & 149.2 & 44.9 & $0.337-0.783-2.647$ \\
\hline $\mathrm{Cu}$ & 142.7 & 42.5 & $-0.080-1.390-2.927$ \\
\hline $\mathrm{Fe}$ & 81.2 & 27.7 & 4.0311 .7022 .407 \\
\hline $\mathrm{Mn}$ & 5.1 & 5.8 & 4.2444 .2384 .144 \\
\hline
\end{tabular}

Figure 5 shows that $\Delta \mathrm{G}$ 。 varies inversely with temperature. As shown in Table $2, \Delta \mathrm{G}^{\circ}$ values were negative for $\mathrm{Cu}$ and $\mathrm{Ni}$, suggesting that the process was feasible and spontaneous for these two metals. The increase in $\Delta \mathrm{G}^{\circ}$ values with temperature, on a negative scale for $\mathrm{Cu}$ and $\mathrm{Ni}$ (Table 2), shows larger spontaneity at higher temperatures, thus implying an increased probability of the sorption process. For Fe 
and $\mathrm{Mn}$, the biosorption process is thermodynamically non-spontaneous, as indicated by the positive $\Delta \mathrm{G}^{\circ}$ values across all the temperature values used herein (Table 2 ). $\Delta \mathrm{H}^{\circ}$ values are positive for all metals signifying the endothermic nature of the adsorption process. $\Delta S^{\circ}$ values were positive, indicating an increase in the degrees of freedom on the surface of the sorbent and disorder of the system. This must have been accompanied by a considerable change in surface configuration of the bio sorbent due to strong metal affinity for the bio sorbent. Furthermore, the positive $\Delta S^{\circ}$ values may also indicate that ion exchange occurs and brings about steric hindrances (Lyubchik et al., 2012). Thus, for the adsorption reaction to proceed spontaneously, $\Delta \mathrm{G}^{\circ}<0, \Delta \mathrm{S}^{\circ}>0$ and $\Delta \mathrm{H}^{\circ}>0$.

\subsection{Adsorption isotherms}

\subsubsection{Langmuir and Freundlich isotherms}

Table 3

Equilibrium parameters evaluated from the Langmuir and Freundlich isotherms (S1).

\begin{tabular}{|llll|}
\hline Metal & Langmuir & Freundlich & \\
& $\mathrm{RL}\left(\mathbf{d m}^{3} / \mathbf{g}\right) \mathbf{q m}(\mathbf{m g} / \mathbf{g}) \mathbf{b}(\mathrm{L} / \mathbf{g}) \mathbf{R}^{2}$ & $\mathrm{~K}_{\mathbf{f}} \mathbf{R}^{2}$ & \\
\hline $\mathrm{Cu}$ & 0.060 .110 .740 .99 & 43.91 & 0.350 .99 \\
\hline $\mathrm{Ni}$ & 0.040 .121 .330 .99 & 4444.53 & 0.250 .99 \\
$\mathrm{Fe}$ & 0.151 .470 .100 .99 & 754.57 & 0.780 .99 \\
$\mathrm{Mn}$ & 0.440 .010 .010 .80 & 66.67 & 8.460 .94 \\
\hline
\end{tabular}

Table 3 shows that the experimental data for $\mathrm{Cu}, \mathrm{Ni}$, and $\mathrm{Fe}$ could be well represented by the Langmuir and Freundlich models as indicated by the $R^{2}$ values of 0.99 . $R_{L}$ values lie in the range $0<R_{L} \leq 1$, showing the suitability of Moringa seeds as a bio sorbent for the adsorption process. The affinity of Moringa seeds for the metal ions followed the order $\mathrm{Ni}>\mathrm{Cu}>\mathrm{Fe}>\mathrm{Mn}$ as shown by the corresponding 'b' values of $1.33,0.74,0.10$, and 0.01 , respectively. High ' $b$ ' values reflect the high affinity of the bio sorbent for the metal. A similar trend was obtained for the adsorption capacity $\left(\mathrm{q}_{\mathrm{m}}\right)$ except for Fe, which showed an anomaly with the highest value of $1,47 \mathrm{mg} / \mathrm{g}$. This could have been due to steric hindrance effects of the larger $\mathrm{Fe}^{2+}$ ion on the adsorption of smaller $\mathrm{Cu}^{2+}$ and $\mathrm{Ni}^{2+}$ ions. Furthermore, being highly paramagnetic, $\mathrm{Fe}$ is more strongly attracted by the magnetic field (probably originating from the biosorbent) than the weakly paramagnetic $\mathrm{Ni}$ and $\mathrm{Cu}$. (Table 1)

\subsection{Temkin and Dubinin- Radushkevich models}


Table 4

Temkin and Dubinin- Radushkevich

parameters

\begin{tabular}{|l|}
\hline Metal Cu Ni Fe Mn \\
Temkin \\
B(J/mol) 19.4416 .530 .800 .52 \\
AT(L/g) 1.21 1.21700 .3247 .73 \\
R2 0.970 .910 .990 .99 \\
Dubinin-Radushkevich \\
KDR(mol12/KJ2) 0.0118 .851 .58571 .91 \\
Qm(mg/g) 6.284 .384 .098 .46 \\
R2 0.87 0.66 0.83 0.83 \\
Es(J/mol) 13.610 .230 .800 .04
\end{tabular}

Table 4 shows that the adsorption process is best described by the Temkin model. The low $A_{T}$ and $B$ values signify the ionic exchange nature of the adsorption process.

\subsection{Adsorption Kinetics}

Table 5

Adsorption Kinetics Parameters

\begin{tabular}{|l|l|}
\hline \multicolumn{2}{|l|}{ Pseudo First Order Psedo 2nd order } \\
$\mathbf{K}_{\mathbf{1}} \mathbf{q} \mathbf{e}_{\mathbf{1}} \mathbf{R}^{2} \mathbf{K}_{\mathbf{2}} \mathbf{q e _ { \text { calc } }} \mathbf{q e _ { \text { exp } } \mathbf { R } ^ { 2 }}$ \\
\hline Ni 0.028139 .120 .9940 .250 .2140 .1860 .995 \\
Cu 0.00316 .1770 .3970 .7480 .1640 .1500 .977 \\
Fe 0.0211 .5610 .0960 .0305 .0633 .4690 .886 \\
Mn 0.01614 .490 .3510 .0080 .3720 .2170 .476 \\
\hline
\end{tabular}

Table 5 shows that the 2 nd order model best describes the adsorption kinetics of $\mathrm{Ni}$ and $\mathrm{Cu}$, thus implying a chemisorption mechanism consistent with monolayer adsorption. $\mathrm{qe}_{\text {calc }}$ is in strong agreement with qe $e_{\text {expt }}$ for these two metals, thus further confirming the suitability of the pseudo 2 nd order model in describing the adsorption process. However, the model was insufficient to represent the experimental data for Fe and Mn.

3.6 Re- use of Moringa Seeds as a bio-sorbent Fig.6 Variation of metal removal with the number of recycles of $\mathrm{MO}$ seed extract. 
From the second to the third cycle, metal removal efficiency decreased from $63-39 \%, 47-27 \%, 55-11 \%$, and $19-13 \%$ for $\mathrm{Ni}, \mathrm{Cu}, \mathrm{Fe}$, and Mn, respectively (Fig. 6). Thus, implying that the seeds extract can be effectively re-used for metal removal for two cycles. The observed trend could be attributed to the fewer remaining active sites for metal binding after each cycle.

\subsection{Desorption studies}

Table 6

percentage amount of metal recovered from metal loaded milled MO seeds.

\begin{tabular}{|lll|}
\hline $\begin{array}{l}\text { Concentration/mg } \\
\text { Metal Original After agitation leached from }\end{array}$ & $\begin{array}{l}\text { Adsorbed from } \\
\text { SAME }\end{array}$ & \% leached from MLSE \\
\hline Ni 0.1713 .9713 .80 & & \\
Cu 0.119 .379 .26 & 18.62 & 74.09 \\
Fe 0173.32173 .32 & 15.06 & 61.50 \\
Mn 017.0617 .06 & 366.26 & 47.32 \\
\hline
\end{tabular}

The solution of $0.05 \mathrm{M} \mathrm{HNO}_{3}$ was able to leach all metal ions from metal-loaded $\mathrm{MO}$ seeds extract except for $\mathrm{Fe}$, which had below $50 \%$ leaching efficiency (Table 6 ). This indicates the possibility of recycling spent $\mathrm{MO}$ seeds extract for further metal removal in acidic mineral waters.

\subsection{Antimicrobial Activity}

\subsubsection{Effect of MO seed extract on coliforms}

Total coliform inhibition seemed to increase with MO dosage reaching a maximum of $100 \%$ for the aqueous extract and $98.2 \%$ for the crude extract at $150 \mathrm{mg} / \mathrm{I} \mathrm{MO}$ dosage, as shown in Fig. 7 . The increase was proven by ANOVA (Table S2) to be statistically significant at the $5 \%$ significance level, with $n=3$, with the difference in dosages being the most probable factor.

\subsubsection{Effect of MO seed extracts on HPC}

HPC load reduction increases with increasing MO dosage, reaching maximum reductions of $90.5 \%$ and $86.1 \%$ at $150 \mathrm{mg} / \mathrm{I} \mathrm{MO}$ dosage for the crude extract and raw extract, respectively (Fig. 8). The increase is statistically significant at the $5 \%$ significance level and is probably influenced by the difference in the seed extracts used (Table S2). The findings depicted in Fig. 7 and Fig. 8 agree with those of authors such as Atieno et al. (2011), Mangale et al. (2012) and Amagloh, and Benang (2009. The observed bacterial load reductions could be due to antimicrobial properties of the bioactive agent, 4 -alpha rhamnosyloxybenzyl isothiocyanate (Masden et al., 1987), which is presumed to act by disrupting the cell membrane causing leakage of cytoplasmic content and killing the bacterial cell (Walter et al., 2011; Arora et al., 2013). Furthermore, Munyanziza and Yongabi (2007) reported that the aqueous extract contains 
higher levels of pterygospermin, an antibiotic agent which destroys microorganisms in water. The increase in total bacterial load reduction with $\mathrm{MO}$ dosage could be due to more bioactive agents available to interact with the bacteria at higher $\mathrm{MO}$ dosages. The enhanced effectiveness shown by the aqueous extract could be explained by considering that the aqueous extract constitutes mainly of the protein component of the seeds, thus implying a higher concentration of the bioactive agent and consequently higher antimicrobial activity than the raw extract.

These findings are encouraging since they meet the EPA drinking water standards which stipulate zero levels for total coliforms and E.coli in drinking water. The presence of coliforms is an indirect indication of dangerous pathogens in drinking water, thus implying adverse health risks on humans.

\subsection{Chemical composition of $\mathrm{MO}$ seeds}

Table 7

XRF analysis of raw and loaded MO seeds

\begin{tabular}{|lll|}
\hline Constituent & Raw & \multicolumn{2}{c|}{ loaded $\mathrm{MO}$} \\
\hline & $\mathrm{MO}$ & \multicolumn{1}{|c|}{} \\
\hline $\mathrm{MgO}$ & 0.334 & 0.178 \\
\hline $\mathrm{Al}_{2} \mathrm{O}_{3}$ & 0.0472 & 0.0512 \\
\hline $\mathrm{SiO}_{2}$ & 0.111 & 0.115 \\
\hline $\mathrm{P}_{2} \mathrm{O}_{5}$ & 1.41 & 1.64 \\
\hline $\mathrm{SO}_{3}$ & 4.05 & 1.68 \\
\hline $\mathrm{Cl}$ & 0.0404 & 0.0344 \\
\hline $\mathrm{K}_{2} \mathrm{O}$ & 0.782 & 0.226 \\
\hline $\mathrm{CaO}$ & 0.193 & 0.148 \\
\hline $\mathrm{MnO}$ & 0.00270 & 0.0903 \\
\hline $\mathrm{Fe} \mathrm{O}_{3}$ & 0.0132 & 0.714 \\
\hline $\mathrm{NiO}$ & 0.00140 & 0.0152 \\
\hline $\mathrm{CuO}$ & 0 & 0.0214 \\
\hline $\mathrm{ZnO}$ & 0.00490 & 0.00610 \\
\hline $\mathrm{SrO}$ & 0.000700 & 0.000800 \\
\hline $\mathrm{BaO}$ & 0.0279 & 05.1 \\
\hline $\mathrm{C}$ & 93.0 & \\
\hline
\end{tabular}


Table 7 shows that $\mathrm{C}$ is the principal constituent of the $\mathrm{MO}$ seeds. After metal-loading, the proportions of $\mathrm{Ni}^{2+}, \mathrm{Cu}^{2+}, \mathrm{Fe}^{2+}$, and $\mathrm{Mn}^{2+}$ increased, probably due to the biosorption of these metals onto active $\mathrm{MO}$ binding surfaces. The ratios of $\mathrm{Ca}^{2+}, \mathrm{Mg}^{2+}, \mathrm{K}^{2+}$, and $\mathrm{Ba}^{2+}$ decreased as these were most likely involved in the ion-exchange mechanism of adsorption and were therefore exchanged with metal ions in the active binding sites (Gupta et al., 2013).

\subsection{MO seed characterisation}

Figure 9 (a) shows the FTIR spectrum for MO seeds before metal loading. The spectrum exhibits a broad peak at $3284.30 \mathrm{~cm}^{-1}$ due to the stretching vibration of phenolic hydroxyl group - $\mathrm{OH}$ (Packialakshmi et al., 2014). The $-\mathrm{OH}$ group represents hydrogen bonding and has been predominant in the protein and fatty acid structures of the MO seeds (Vanessa et al., 2013). The $-\mathrm{C}-\mathrm{H}$ stretching of $-\mathrm{C}=\mathrm{O}$ and $/-\mathrm{CH}_{3}$ functional groups could have contributed to the absorption peaks observed at $2919.49 \mathrm{~cm}^{-1}$ and $2847.49 \mathrm{~cm}^{-1}$ while the sharp and elongated peak at $1650.34 \mathrm{~cm}^{-1}$ could be assigned to $-\mathrm{C}=\mathrm{C}$ stretch or $-C=O$ group of carboxylic acids (Nyoni et al., 2017). The peak at $1538.06 \mathrm{~cm}^{-1}$ could be associated with -C-N stretching and $-\mathrm{N}-\mathrm{H}$ deformation in the peptide $\left(-\mathrm{CONH}_{2}\right)$ group linking the seed proteins (Araújo et al., 2010). Symmetric bending of $\mathrm{CH}_{3}$ may have occurred at peak $1414.9670 \mathrm{~cm}^{-1}$, while the stretching vibration of $-\mathrm{C}=\mathrm{O}$ in the ester group could be represented by the peak $1231.7070 \mathrm{~cm}^{-1}$. Peak $1052.6470 \mathrm{~cm}^{-1}$ probably correspond to $-\mathrm{O}-\mathrm{H}$ stretching of polysaccharides, whereas the presence of weak peaks at $925.5970 \mathrm{~cm}^{-1}$ and $792.0770 \mathrm{~cm}^{-1}$ indicates possible out-of-plane bend an ester $\left(-0-\mathrm{CH}_{3}\right.$ and alkene $(-\mathrm{C}=\mathrm{C}-)$ group respectively.

Figure 9 (b) presents the FTIR spectrum of MO seeds after the biosorption process. Some shifts in the peaks were noted; peak $3284,30 \mathrm{~cm}^{-1}$ shifted to $3293.70 \mathrm{~cm}^{-1}, 2919.49$ shifted to $2925.17 \mathrm{~cm}^{-1}$, $2847.50 \mathrm{~cm}^{-1}$ to $2857.00 \mathrm{~cm}^{-1}, 925.60 \mathrm{~cm}^{-1}$ to $871.78 \mathrm{~cm}^{-1}$ and $792.08 \mathrm{~cm}^{-1}$ to $789.72 \mathrm{~cm}^{-1}$. These shifts were probably caused by the $-C=0$ stretching (Ali et al., 2015), which can be linked to esters, saturated aliphatic groups, and a, $\beta$-unsaturated aldehydes, and ketones (Rahim et al., 2014) owing to the heterogeneous nature of the $\mathrm{MO}$ seeds. The lipid component of the seeds is represented by the carbonyl amides in the protein portion, which may be responsible for the shoulder peak at $1736.95 \mathrm{~cm}^{-1}$ (Vanessa et al., 2012). The resultant repeated shift of the $-\mathrm{C}=0$ stretching implies that the $-\mathrm{C}=0$ group could be responsible for binding/reacting with $\mathrm{Me}^{2+}$ ions at the surface of the $\mathrm{MO}$ seeds. The presence of peaks 2925.16 confirms the protein structure of $\mathrm{MO}$ seeds and $2856.99 \mathrm{~cm}^{-1}$, which may be respectively assigned to symmetrical and asymmetrical $\mathrm{C}-\mathrm{H}$ stretching of the $-\mathrm{CH}_{2}$ moiety in fatty acids (Vanessa et al., 2012). The evolution of new peaks at $234470.06 \mathrm{~cm}^{-1}$ and $1736.96 \mathrm{~cm}^{-1}$ suggests a change in the natural composition of $\mathrm{MO}$ seeds due to the biosorption process.

\section{Conclusion}

\section{Conclusion}


The MO seed extract demonstrated that they could be used as effective biosorbent material for the removal of $\mathrm{Ni}, \mathrm{Cu}$, and $\mathrm{Fe}$ in acidic mineral effluents. Mn removal was very poor, probably due to its low affinity for the MO biosorbent. The Langmuir model and second-order kinetics best described the adsorption process for $\mathrm{Ni}, \mathrm{Cu}$, and $\mathrm{Fe}$, with ion exchange and/chemisorption being the potential mechanisms of adsorption. The adsorption process for all metal ions was endothermic but only thermodynamically feasible for $\mathrm{Ni}$ and $\mathrm{Cu}$. Metal removal followed the order: $\mathrm{Ni}>\mathrm{Cu}>\mathrm{Fe}>\mathrm{Mn}$, with ionic radius and electronegativity being the major influencing factors. Metal removal efficiency increased with $\mathrm{pH}$, time, \% solid loading, and temperature till the attainment of sorption equilibrium. Optimum operating conditions achieved were $\mathrm{pH}=3$, Temperature $=308 \mathrm{~K}$, solid loading $=10 \%$, and residence time of 90 minutes. Metal removal in the second cycle of the desorption treatment was quite low, thus indicating that spent seed extract could be effectively recycled for only two cycles. The seeds also seem to exhibit high antimicrobial activity as indicated by the $100 \%$ total bacterial load reduction and inhibition on E.Coli and HPC. However, at $150 \mathrm{mg} / \mathrm{l} \mathrm{MO}$ dosage, the aqueous extract proved to be more effective than the raw extract achieving maximum reductions of $100 \%$ and $90.5 \%$ in coliform and HPC inhibition, respectively. Thus, it is recommended to use the raw extract as an antimicrobial agent in the treatment of acidic mineral effluents.

Overall, the research findings indicate that $\mathrm{MO}$ seed extracts could be effectively used as alternative antimicrobial agents and biosorbent in treating acidic mineral effluents for disinfection and heavy metal removal, respectively. Thus, providing an alternative AMD treatment method that is cost-effective, easily accessible, environmentally friendly (forms bio-degradable sludge), and poses no potential health risks, particularly on humans

\section{Declarations}

\section{Funding}

Not applicable

The authors have no relevant financial or non-financial interests to disclose.

\section{Conflicts of interest/Competing interests.}

The authors declare no conflict/competing interests.

\section{Ethics approval and Consent to participate.}

Not applicable

\section{Availability of data and material}

All data generated or analyzed during this study are included in this published article (and its supplementary information files). 


\section{Code availability}

Not applicable

\section{Authors' contributions}

All authors contributed to the study conception and design. Material preparation, Experiments, data collection and analysis were performed by Pauline Ncube. The first draft of the manuscript was written by Pauline Ncube and proofread by Freeman Ntuli and Thabo Falayi. All authors read and approved the final manuscript.

\section{Consent for publication}

The authors give consent to the publication of this manuscript and further declare that this work has not been published before; that it is not under consideration for publication anywhere else and that its publication has been approved by the University of Johannesburg.

\section{Acknowledgments}

The authors gratefully acknowledge the research support extended by the Department of Chemical Engineering, University of Johannesburg.

\section{References}

1. Ali EN, Alfarra SR, Yusoff MM, Rahman MdL (2015) Environmentally Friendly Bio sorbent from Moringa Oleifera Leaves for Water Treatment. International Journal of Environmental Science and Development 6, 101-105.

2. Ali NA, Muyibi SA, Salleh HM, Zahangir MD (2010) "Production of Natural Coagulant from Moringa Oleifera Seed for Application in Treatment of Low Turbidity Water." Journal of Water Resource and Protection 2, 259-266.

3. Amagloh FK, Benang A (2009) Effectiveness of Moringa Oleifera Seeds as a Coagulant for Water Purification. Afr J Agric Res 4:119-123

4. Araújo CST, Carvalho D, Rezende H, Almeida C, Coelho LL,S, Coelho L,M, Marques NM,M, Alves TL, V, N., 2013. Bioremediation of Waters Contaminated with Heavy Metals Using Moringa Oleifera Seeds as Biosorbent. Journal of the Brazilian Chemical Society 21, 1727-1732.

5. Arora DS, Onsare JG, Kaur H (2013) Bioprospecting of Moringa (Moringaceae): Microbiological Perspective. Journal of Pharmacognosy Phytochemistry 1:193

6. Atieno W, Wagai S, Arama S, Ogur P, J., 2011. Antibacterial Activity of Moringa Oleifera and Moringa Stenopetala Methanol and $\mathrm{n}$-hexane Seed Extracts on Bacteria Implicated in Water Borne Diseases. African Journal of Microbiology Research 5, 153-157

7. Bhatt V (2015) Essentials of coordination chemistry. United Kingdom, Academic press publisher 
8. Bukar A, Ubar A, Oyeyi TI (2010) Antimicrobial Profile of Moringa Oleifera Lam extracts against some Food- borne microorganisms. Bayero Journal of Pure and Apllied Science 3, 43-48

9. Cochrane EL, Lua Sb, Gibb SWa, Villaescusa I (2006) A comparison of low-cost bio-sorbents and commercial sorbents for the removal of copper from aqueous media. J Hazard Mater B137:198-206

10. Deepti SP, Sanjay M,C, John U,K (2016) A review of technologies for Manganese removal from wastewaters. Journal of Environmental Chemical Engineering 4, 468-487

11. Delvin S (2002) Amino acids and proteins, 1 st edn. IVY publishing house, New Delhi

12. Devarakonda V, Moussa N,A, VanBlaricum V, Ginsberge M, Hock V (2010) Kinetics of free Chlorine decay in Water distribution Networks, Proc. The World Environmental and Water Resources Congress, ASCE, Rhode Island, May 16-20

13. EPA: Environmental Protection Agency. National Primary Drinking Water Regulations. Accessed on 17 (April 2020) from: http://www.biovir.com/Images/pdf054.pdf

14. Expert Team of the Inter-Ministerial Committee (2010) Mine water management in the Witwatersrand Gold Fields with special emphasis on acid mine drainage. In: Report to the Inter-Ministerial Committee on Acid Mine Drainage. Pretoria, Department of Water, Pretoria

15. Falayi T (2014) Adsorption of Heavy Metals and Neutralization of Acid Mine Drainage using Clay Minerals. Masters Dissertation, University of Johannesburg

16. Farooq U, Kozinski JA, Khan M, Athar A, M., 2010. Biosorption of Heavy Metal lons using Wheat based biosorbents - A review of the recent literature. Bio resource Technology 101, 5043-5053

17. Garcia-Fayos B, Arnal JM, Verdu G, Sauri A (2010) Study of Moringa Oleifera Oil Extraction and its Influence in Primary Coagulant Activity for Drinking Water Treatment. Paper presented at the annual meeting for the organisation of CABI, Valencia, 25-29 October.

18. Ghebremichael KA (2004) Moringa seed and pumice as alternative natural material for drinking water treatment. PhD thesis, KTH land, and water resources engineering

19. Giri A (2012) Removal of Arsenic (III) and chromium (VI) from the water using phytoremediation and bioremediation techniques. Dissertation, National Institute of Technology

20. Gorgievskia M, Bo`zic' D, Stankovi'c' V, 'Strbac N, 'Serbulab S (2013) Kinetics, Equilibrium, and Mechanism of $\mathrm{Cu} 2+, \mathrm{Ni} 2+$ and $\mathrm{Zn} 2+$ ions biosorption using wheat straw. Ecological Engineering 58: $113-122$

21. Gupta VK, Ali I, Saleh TA, Siddiqui MN, Agarwal S (2013) Chromium removal from water by activated carbon developed from waste rubber tires. Environmental Science and Pollution Research 20, 12611268.

22. Jahn SAA (1988) Using Moringa seeds as coagulants in developing countries. Journal of American Water Works Association 80, 43-50.

23. Kaser F, Werner C, Nahayo D (1990) Rural water treatment using Moringa oleifera seeds as coagulant. Natural Resources Development 33:33-47 
24. Kumara V, Narayana J, Puttaiah ET, Babu KH (2005) Assessment of surface and sub-surface water of Bhadra river basin near Bhadravathi town Karnataka. Journal of Ecotoxicology \& Environmental Monitoring. 15, 253-261.

25. Lyubchik SI, Lyubchik A,I, Galushko O, Tikhonova L, Vital L,P, J (2012) Kinetics and Thermodynamics of the $\mathrm{Cr}$ (III) Adsorption on the Activated Carbon from Comingled Wastes. Colloidal Surfaces 242:151-158

26. Madsen M, Schlundt J, Omer F,E (1987) Effect of Water Coagulated by Seeds of Moringa Oleifera on Bacterial Concentrations. Journal on Tropical Medical Hygiene 90:101-109

27. Mangale SM, Chonde S, Jadhav G, Raut AS, P, D., 2012. Study of Moringa Oleifera (Drumstick) Seed as a Natural Absorbent and Antimicrobial Agent for River Water Treatment. Journal of Natural Product and Plant Resource 2, 89-100

28. Mohan JS, Bipinraj N, Gidde K, M, R., 2008. Moringa Oleifera Seed as Antibacterial Agent in Water Treatment. Paper for National Conference on Household Water Treatment Technology, at Hindustan College of Sc. And Tech. July 24-25

29. Munyanziza E, Yongabi K, A., 2007. Moringa Peregrina (Forssk.) Fiori In: van der Vossen AM and Mkamilo GS, (Editors)., Wageningen, Netherlands, 2007

30. Muyibi S, Evison A, L.M (1994) Moringa Oleifera Seeds for Softening Hardwater. Water Res 29:10991105

31. Ndabigengesere A, Subba K, Narasiah M (1998) Quality of Water treated by Coagulation using Moringa oleifera seeds. Water Res 32:781-791

32. Nyoni S, Satiya E, Mukaratirwa-Muchanyereyi N, Shumba M (2017) Comparative biosorption of Pb2 + ions from aqueous solution using Moringa oleifera plant parts: Equilibrium, kinetics, and thermodynamic studies. African Journal of Biotechnology, 16, 2215-2231.

33. Packialakshmi N, Naziya S (2014) Fourier transform infrared spectroscopy analysis of various solvent extracts of Caralluma fimbriyata. Asian Journal of Biomedical Pharmaceutical Sciences 4:20

34. Pinto PX, Al-AbedB S, R (2011) Biosorption of Heavy Metals from Mining Influenced Water ontoChitin Products. Chem Eng J 166:1002-1009

35. Rahim M, Vadi M (2014) Langmuir, Freundlich and Temkin Adsorption Isotherms of Propanol on Multi- wall Carbon Nanotube. Journal of Modern Drug Discovery and Drug Delivery Research 19, 1-3.

36. Reddy DHK, Ramana DKV, Seshaiah K, Reddy AVR (2010) Biosorption of Ni(II) from Aqueous phase by Moringa Oleifera Bark, a Low Cost Biosorbent. Desalination 268, 150-157.

37. Sharma V, Paliwal R (2013) Isolation and Characterization of Saponins from Moringa Oleifera (Moringaeceae) pods. J Pharm Sci 32:406-413

38. Vanessa N, Alves VN, Coelho NMM (2012) Selective extraction and preconcentration of chromium using Moringa oleifera husks as bio sorbent and flame atomic absorption spectrometry. Microchemical Journal 109, 16-22 
39. Walter A, Samuel W, Peter A, Joseph O (2011) Antibacterial Activity of Moringa Oleifera and Moringa Stenopetala Methanol and $\mathrm{n}$-Hexane seed Extracts on Bacteria implicated in water borne diseases. African Journal of Microbiology Research 5, 153-157

40. Zhang M (2011) Adsorption Study of Pb(II), Cu(II) and Zn(II) from Simulated Acid Mine Drainage using Dairy Manure Compost. Chem Eng J 172:361-368

\section{Figures}

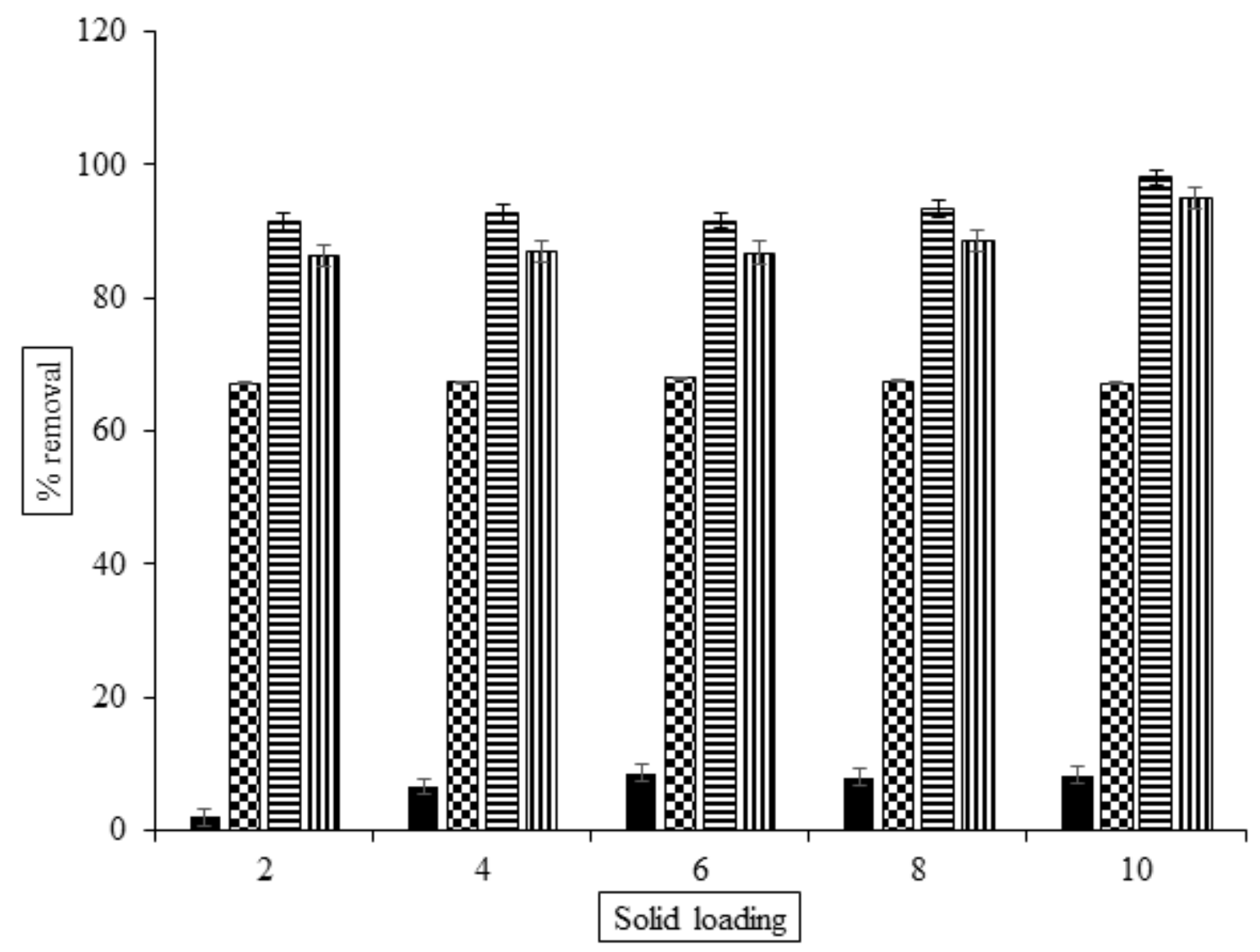

- $\mathrm{Mn} \boldsymbol{\mathrm { F } e} \mathrm{\theta} \mathrm{Ni} \mathbf{m} \mathrm{Cu}$

Figure 1

Variation of metal removal with solid loading. [Conditions: $\mathrm{Co}=20$ ppm Cu, 20 ppm Ni, 100 ppm Mn, 500 ppm Fe, Temperature $=298 \mathrm{~K}$, initial $\mathrm{pH}=3.4$, Time $=4 \mathrm{~h}]$ 


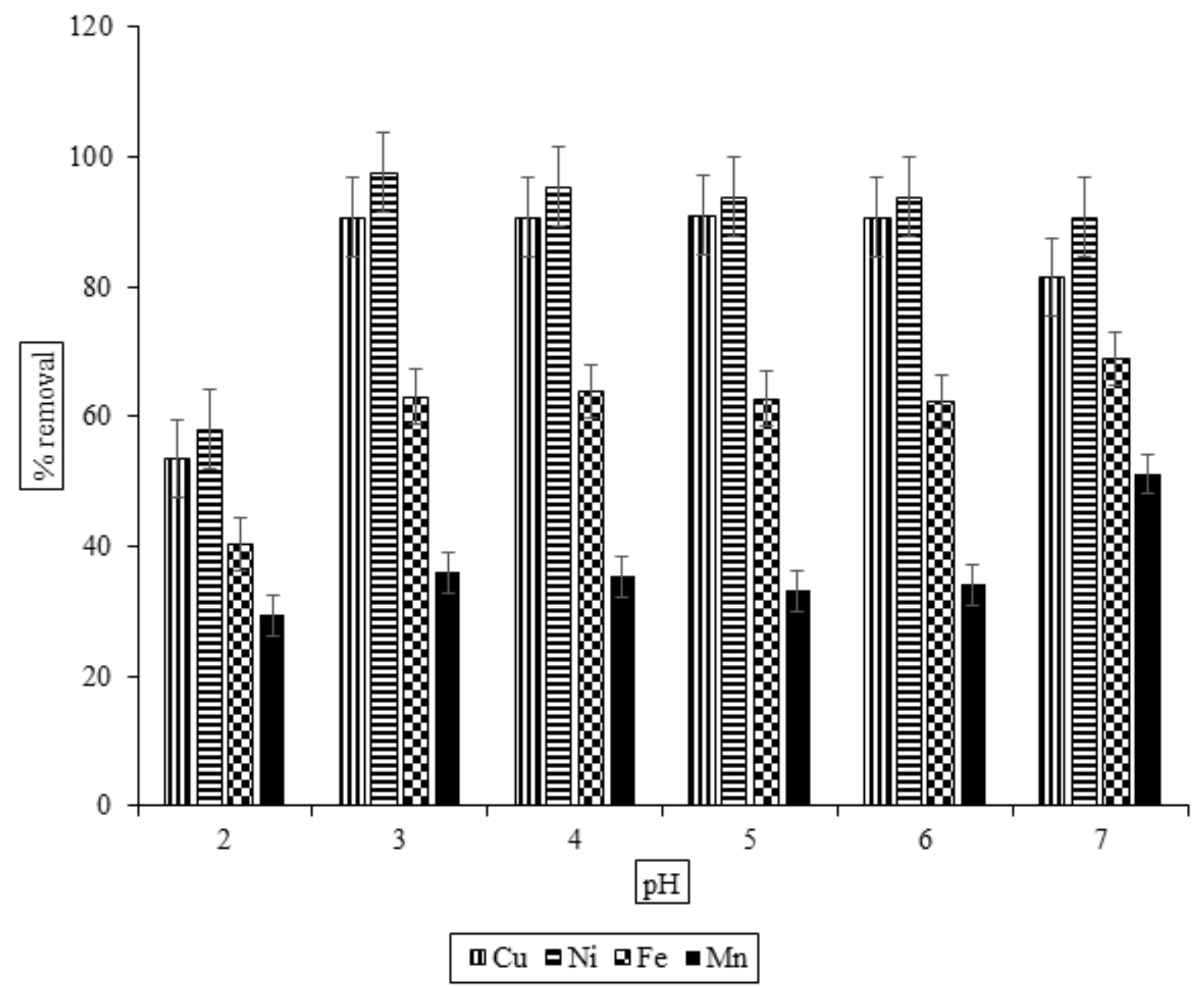

Figure 2

Variation of metal removal with initial pH. [Conditions: $\mathrm{Co}=20 \mathrm{ppm} \mathrm{Cu}, 20 \mathrm{ppm}, \mathrm{Ni}, 100 \mathrm{ppm} \mathrm{Mn}, 500$ ppm Fe; solid loading $=10 \% \mathrm{~m} / \mathrm{v}$, Temperature $=298 \mathrm{~K}$ 


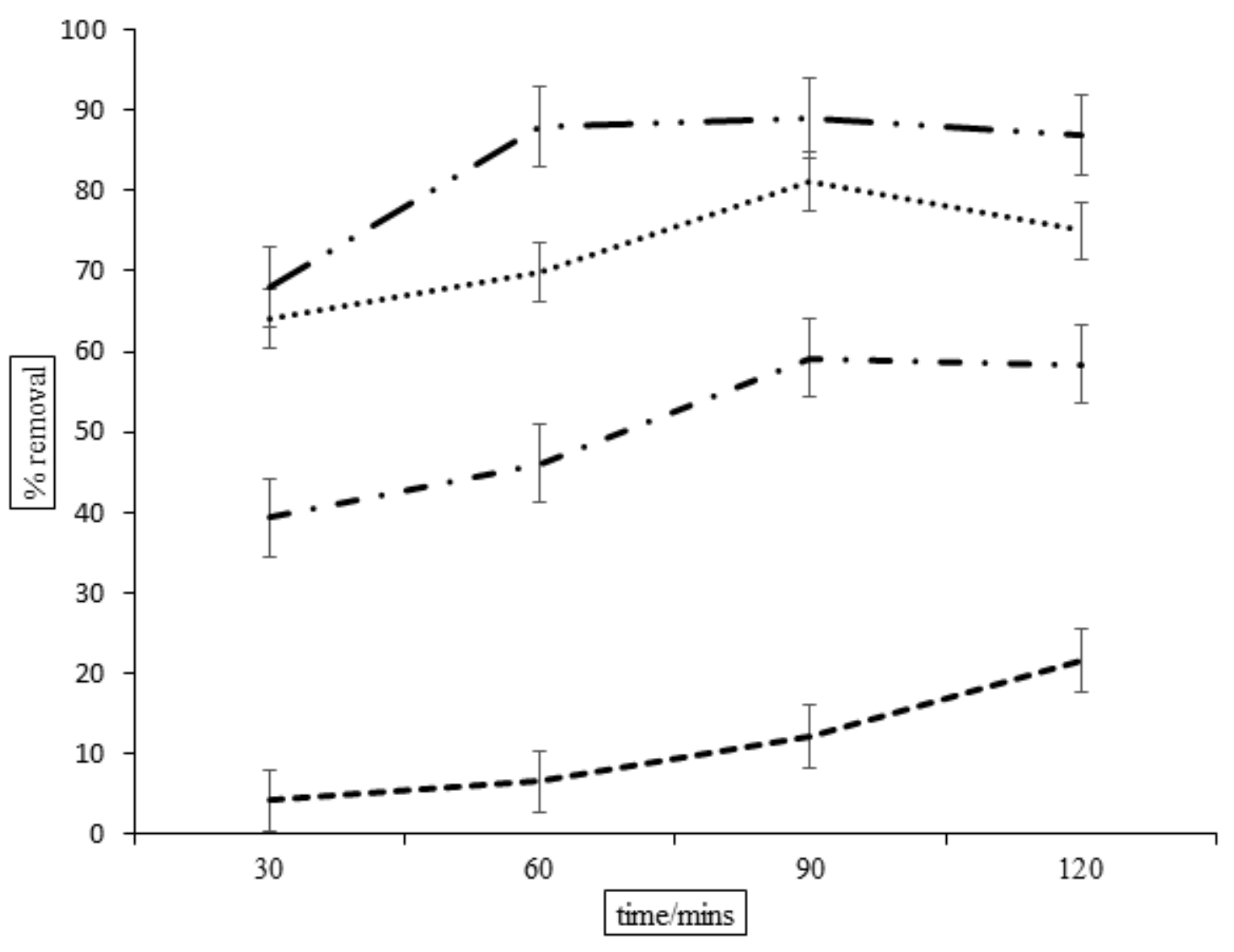

$-\mathrm{Ni}-\cdot \mathrm{Fe}=-\mathrm{Mn} \cdots \cdot \mathrm{Cu}$

Figure 3

Variation of metal removal with contact time. [Conditions: $\mathrm{Co}=20 \mathrm{ppm} \mathrm{Ni}, 20 \mathrm{ppm} \mathrm{Cu}, 100 \mathrm{ppm} \mathrm{Mn,} 500$ ppm Fe; solid loading $=10 \% \mathrm{~m} / \mathrm{v}$, initial $\mathrm{pH}=3$, temperature $=298 \mathrm{~K}]$ 


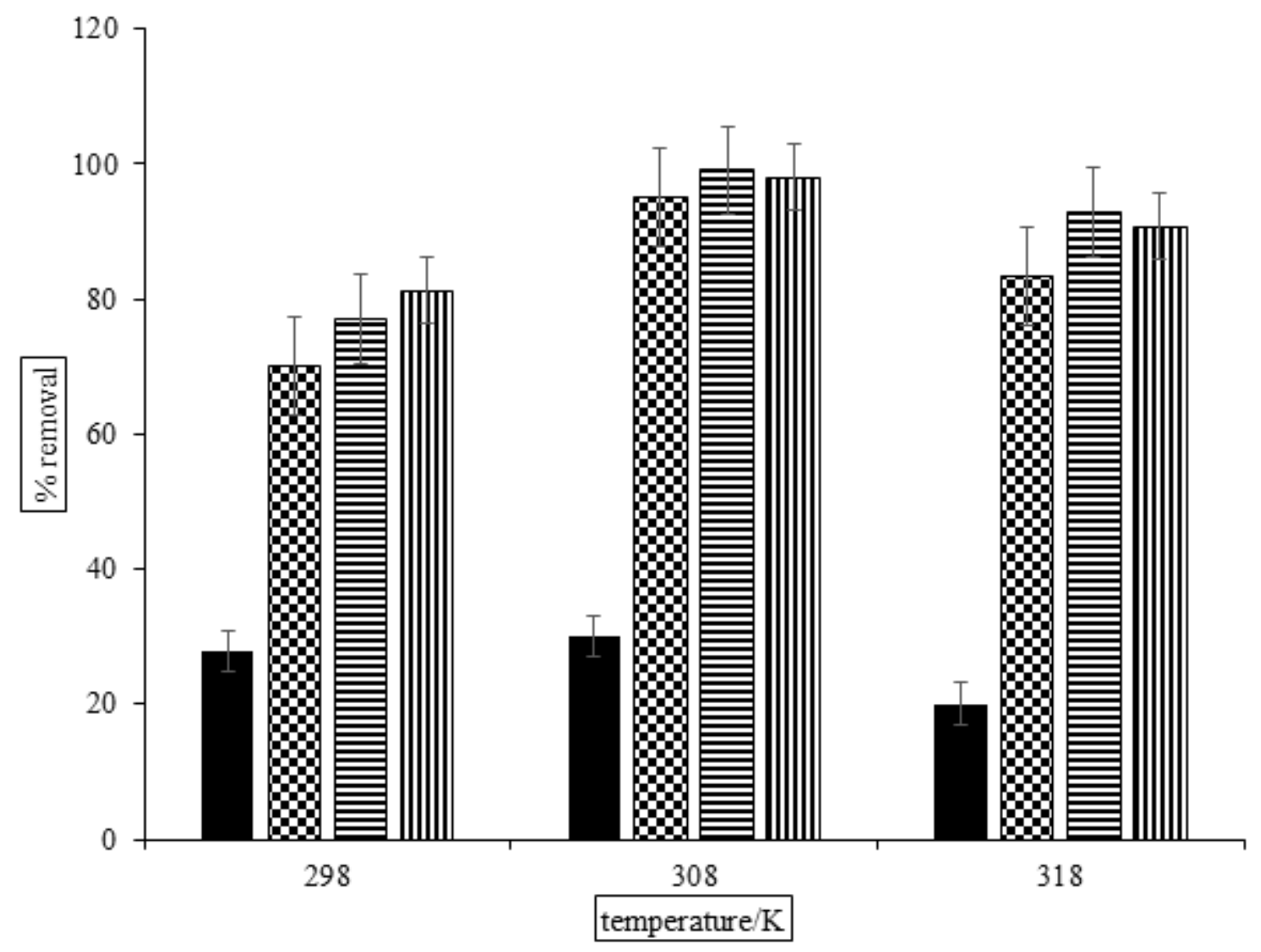

- $\mathrm{Mn} \mathbf{\mathrm { Fe }} \mathrm{\theta \textrm {Ni }} \mathbf{\mathbf { m C u }}$

Figure 4

Variation of metal removal with temperature [Conditions: Co: 20 ppm Cu, 20 ppm Ni, 100 ppm Mn, 500 ppm Fe, initial $\mathrm{pH}=3.0$, solid loading $=10 \% \mathrm{~m} / \mathrm{v}$, time $=90$ mins] 


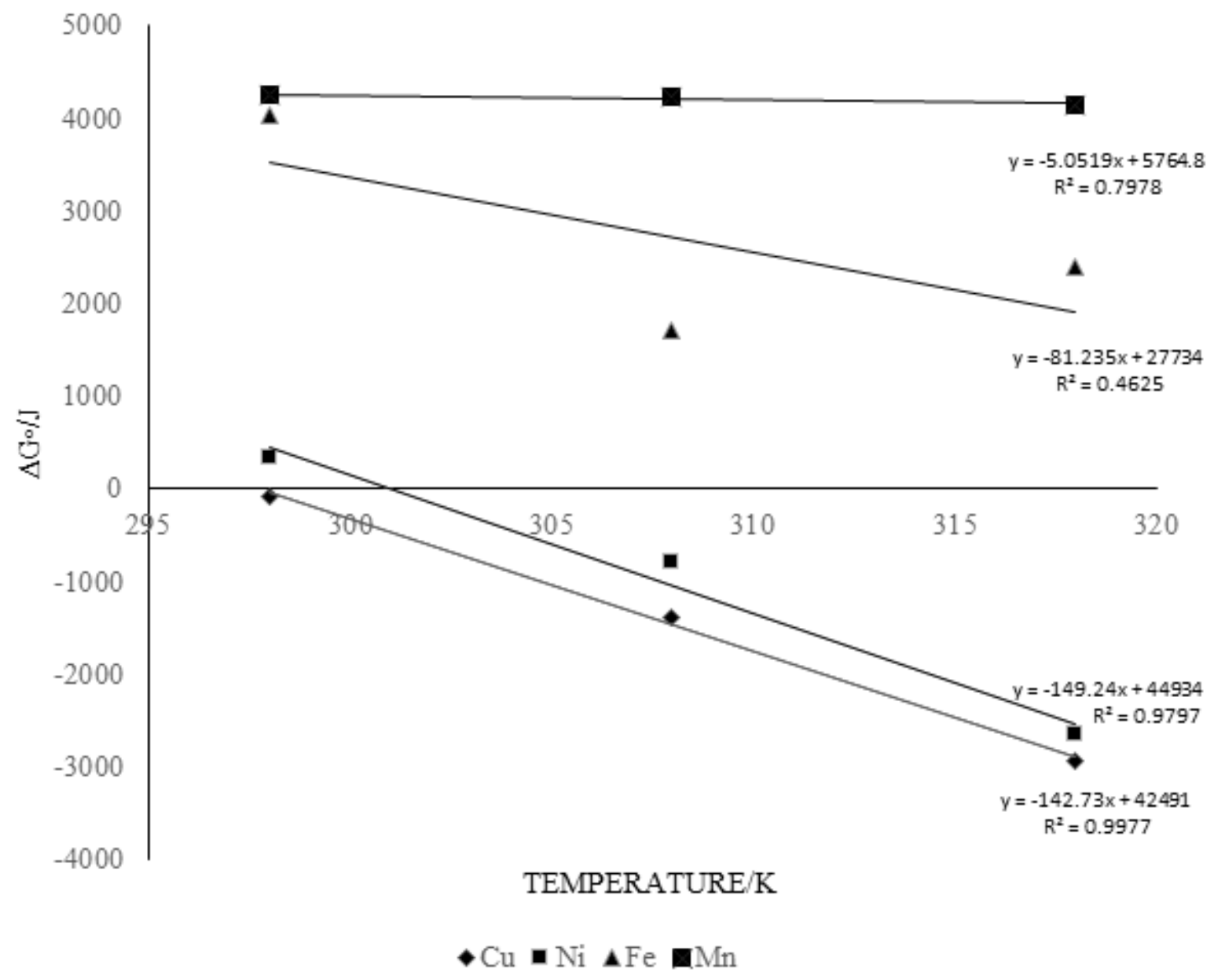

Figure 5

$\Delta \mathrm{G}$ ॰ vs $\mathrm{T}$ plot for $\mathrm{Cu}, \mathrm{Ni}, \mathrm{Fe}$ and $\mathrm{Mn}$ 


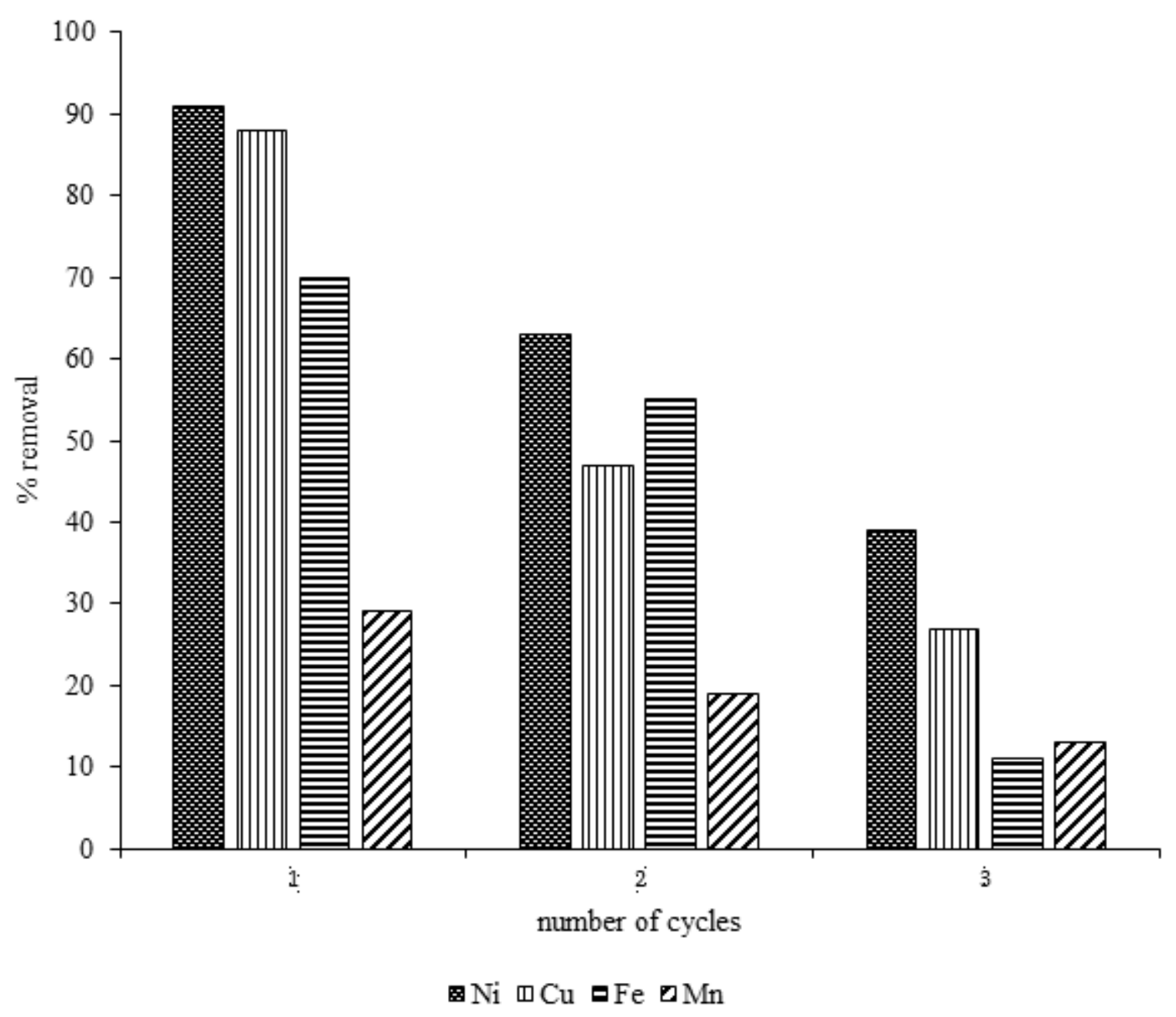

Figure 6

Variation of metal removal with the number of recycles of MO seed extract. 


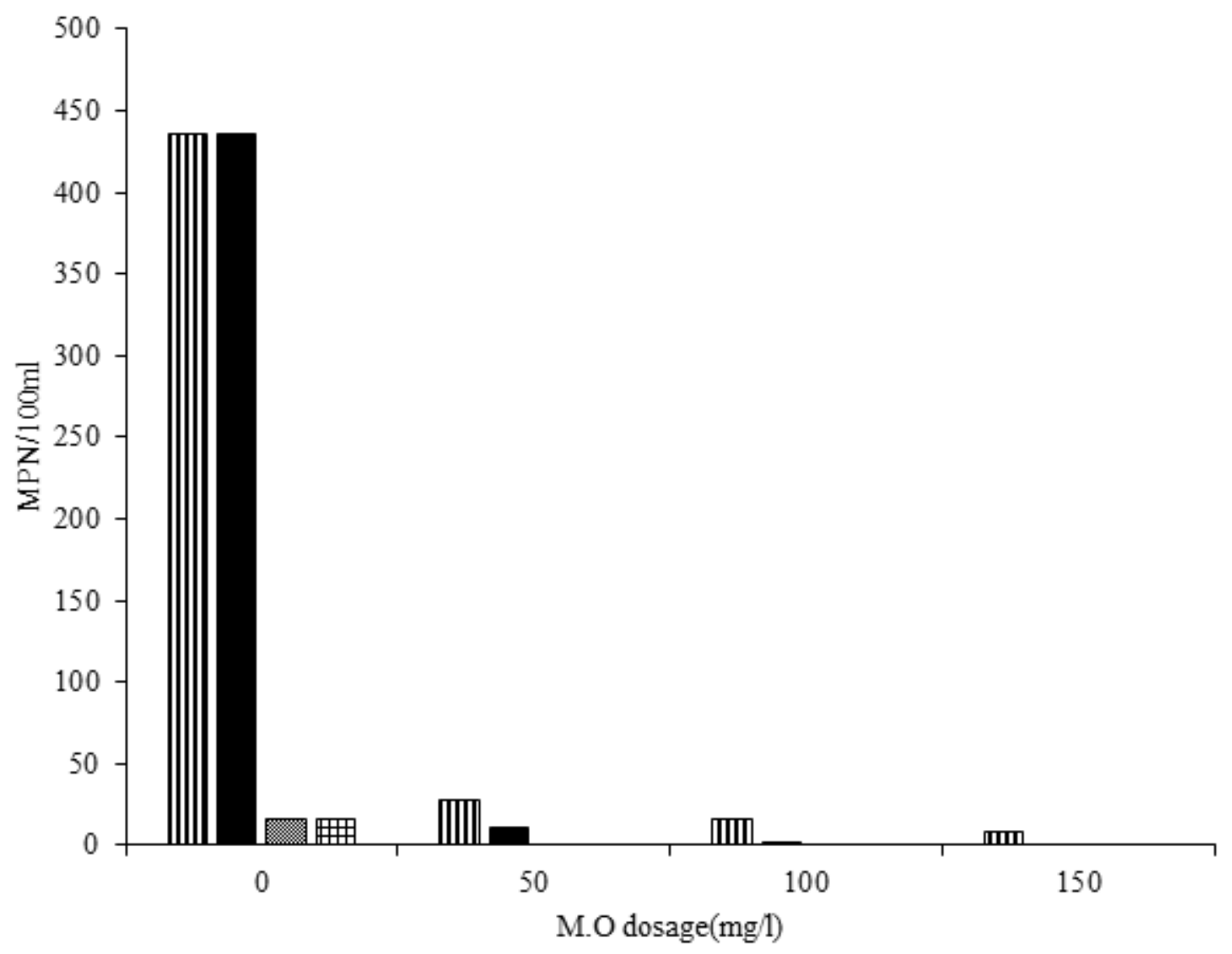

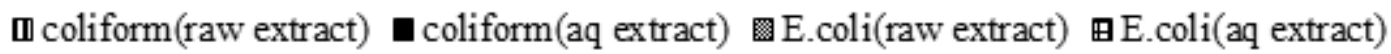

Figure 7

Variation of MPN/100ml of total coliform and E.coli with MO dosage for wastewater treated with raw extract and aqueous extract. 


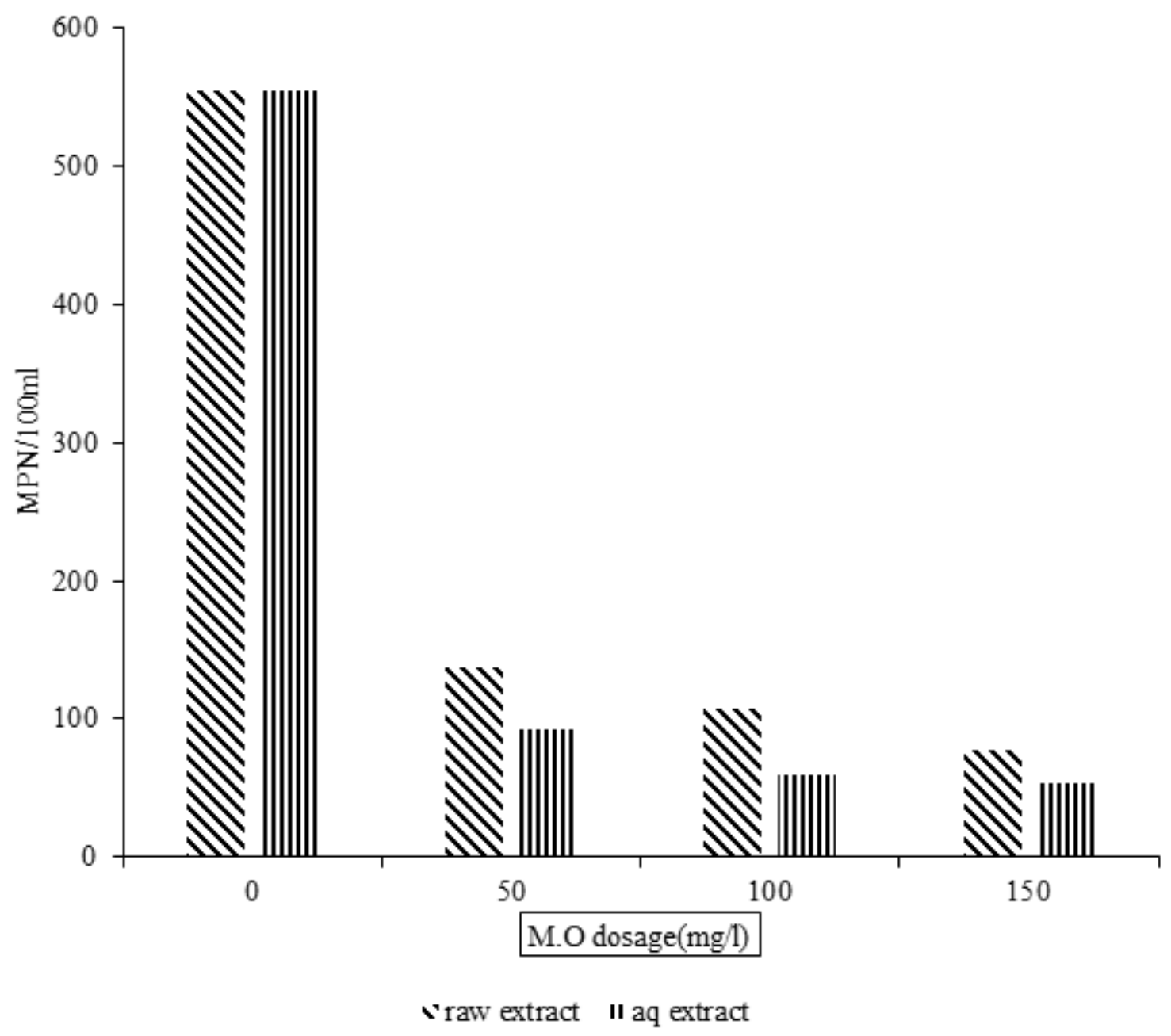

Figure 8

Variation of MPN/100ml with MO dosage for wastewater treated with raw and aqueous extracts. 


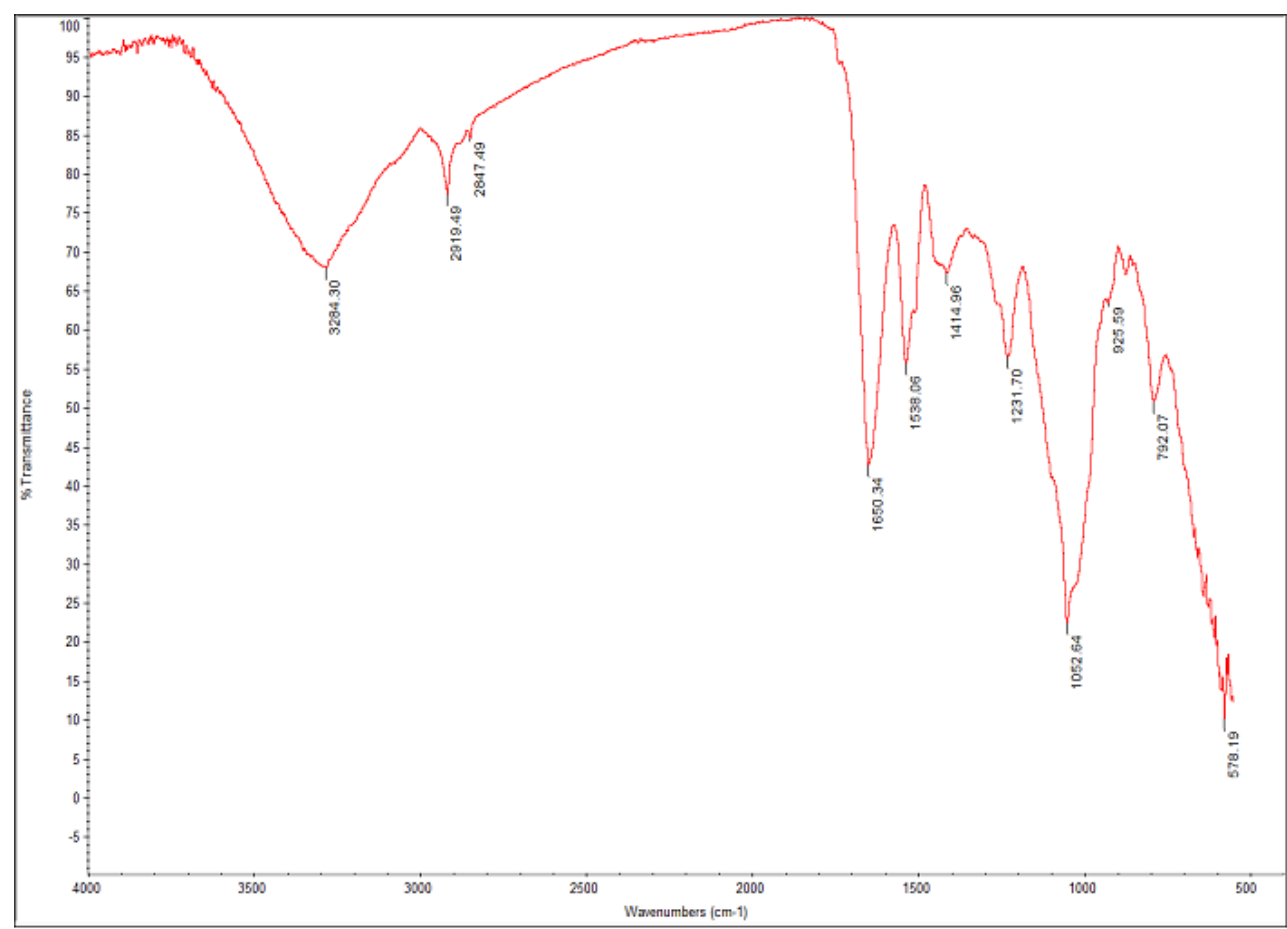

(a)

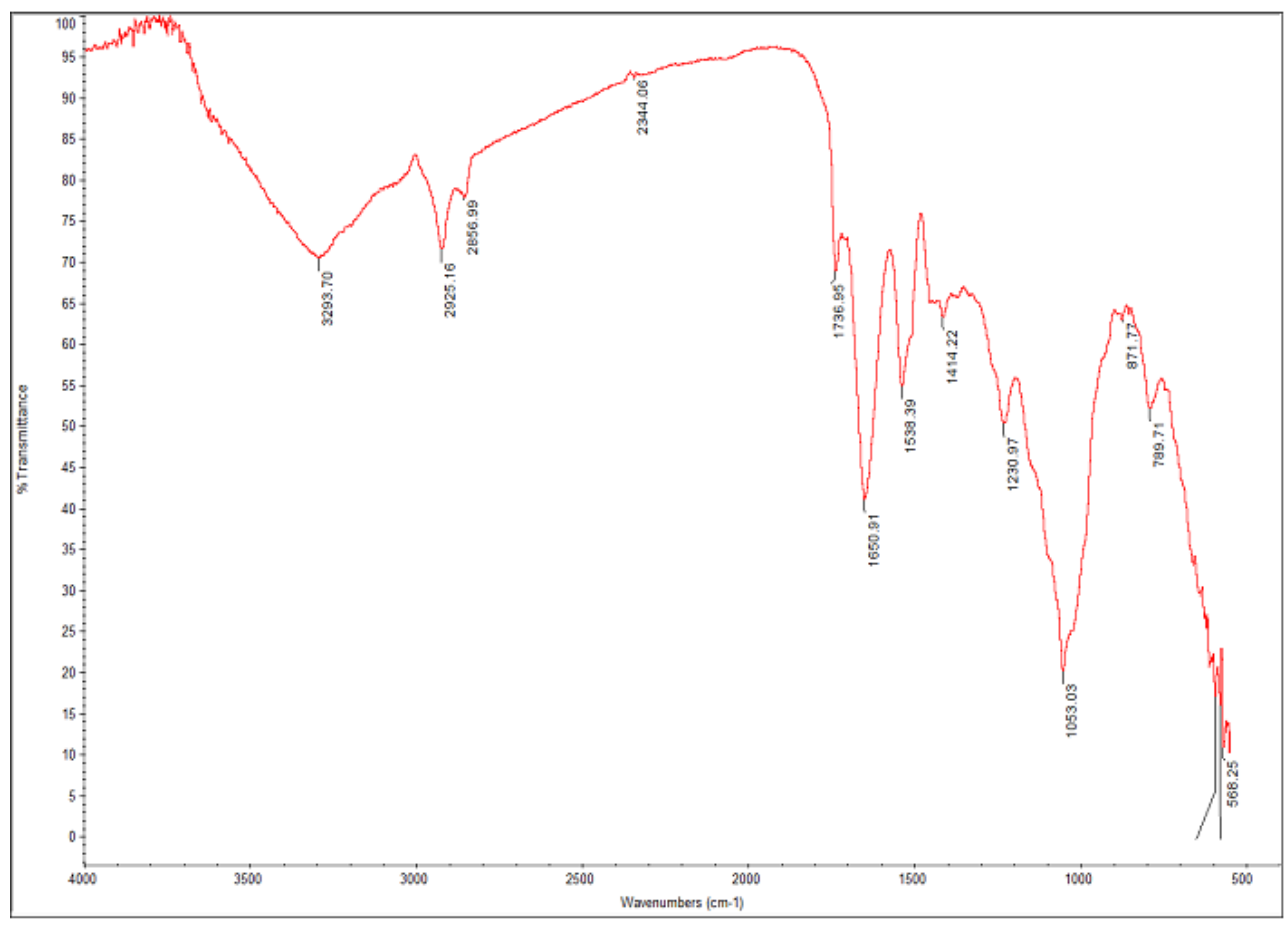

(b)

Figure 9

FTIR spectrum (a) before metal loading (b) after metal loading

\section{Supplementary Files}

This is a list of supplementary files associated with this preprint. Click to download. 
- supplementarydataanovaanalysis.docx

- supplementarydatalangmuirandFreundlichisotherms.docx 